\title{
III. A reply to Professor Kelland's observations in the Philosophical Magazine for November 1842
}

\section{Rev. M. O'Brien}

To cite this article: Rev. M. O'Brien (1843) III. A reply to Professor Kelland's observations in the Philosophical Magazine for November 1842, Philosophical Magazine Series 3, 22:142, 21-22, DOI: $10.1080 / 14786444308621626$

To link to this article: http://dx.doi.org/10.1080/14786444308621626

册 Published online: 01 Jun 2009.

Submit your article to this journal $₫$

Џll Article views: 3

Q View related articles $₫$ 
the picture again faded, by very slow degrees, and on January 2 , 1842, was found quite obliterated. Being then again subjected to the acid vapour, the colour was reproduced. How often this alternation might have gone on I cannot say, the specimen having been mislaid or destroyed. But a portion of such paper photographically impressed with a stamped pattern, accompanies this communication for the satisfaction of any member who may wish to try the experiment. The extreme slowness of the action precludes any prismatic analysis of the process, and it cannot be too often repeated that the use of coloured glasses in such inquiries serves only to mislead. Of dormant photographic impressions generally, whether slowly developing themselves by lapse of time, or at once revivable by stimuli, as well as of the spontaneous fading and disappearance of such impressions, I shall have more to say hereafter, having encountered several very curious cases of the kind in studying the habitudes of gold, platina, \&c. I would here only observe, that a consideration of many such phænomena has led me to regard it as not impossible that the retina itself may be photographically impressible by strong lights, and that some at least of the phanomena of visual spectra and secondary colours may arise from the sensorial perception of actual changes in progress in the physical state of that organ itself, subsequent to the cessation of the direct stimulant.

[To be continued.]

III. A Reply to Professor Kelland's Observations in the Philosophical. Magazine for November 1842. By the Rev. M. O'Brien *.

A S my final reply to Professor Kelland, I beg to state very $A$ briefly the following facts :-

1st. Professor Kelland has given no answer to the questions I asked him, viz. "Why did he bring forward an expression for $v^{2}$ from his 'Theory of Heat' as equivalent to mine, when it most clearly does not account for dispersion independently of the hypothesis of finite intervals?" And again, "Why did he not quote the words which follow this expression in his ' Theory of Heat,' containing his own admission that it was too uncertain to be made use of ?". These questions contain my chief "charges" against Professor Kelland; and since he has not answered them, I conclude that he cannot deny his attempt to create an impression that he had, in his "Theory of Heat,' anticipated my explanation of dispersion.

* Communicated by the Authcr. 
2ndly. Professor Kelland now confesses that his fundamental equations are essentially erroneous. Mr. Earnshaw and myself have fully confuted his strange attempt to set up the plea of misprint and mistranscription.

3rdly. Professor Kelland does not defend his equations in page 159 of the Cambridge Transactions, vol. vi.

4thly. Professor Kelland most unquestionablydenies the existence of a normal vibration in the Edinburgh Transactions, vol. xiv. page 396; and neglects taking the normal vibrations into account in that memoir, which plainly proves how little he then understood of the question of transversal and normal vibrations.

I now therefore am entitled confidently to assert the accuracy of all my assertions respecting Professor Kelland's investigations.

In conclusion, I beg to state that I have nowhere charged Professor Kelland with dishonesty towards M. Cauchy; and that what Professor Kelland calls "my attack upon him" is only my defence against his unprovoled attack upon me; and that when he took upon him to make a public attack upon me, he had no right to expect that I would have been content with a "private explanation."

Dec. 2, 1842 .

IV. A Reply to Professor Kelland's Letter of November 184,2. By S. Earnshaw, M.A., Cambridge, and the Rev. M. O'Brien.

To the Editors of the Philosophical Magazine and Journal. Gentlemen,

PROFESSOR Kelland in your present Number [Dec. 1842.] seeks to avoid the consequences of our arguments by stating that we have been led astray by "a misprint, or rather a mistranscription," and that the quantities we have animadverted upon " are not equal," and that he has "supposed the axis of $y$ to be that along which transmission takes place." We shall reply to these in a reverse order,

1. The Professor says he has supposed the axis of $y$ to be that of transmission.

If the Professor will refer to p. 161 of his Memoir (Camb. Phil. Trans. vol. vi.), he will find that he there states the contrary to be the case in these words: " so that we might at once suppose the direction of transmission to be the axis of $y$, and put $\delta y$ for $\delta \rho$; this, however, $I$ shall not do ;" and as a proof that he did not, we find him near the bottom of the same 